\title{
PERTUMBUHAN DAN PRODUKSI TANAMAN SELADA (Lactuca sativa L.) PADA SISTEM HIDROPONIK NFT DENGAN BERBAGAI KONSENTRASI PUPUK AB MIX DAN GROWMORE
}

\section{GROWTH AND PRODUCTION OF LETTUCE (Lactuca sativa L.) IN NFT HYDROPONIC SYSTEMS WITH VARIOUS CONCENTRATIONS AB MIX AND GROWMORE FERTILIZERS}

\author{
Riama Rita Manullang, Roby, F.Silvi Dwi Mentari, Rusmini \\ 1Politeknik Pertanian Negeri Samarinda, Kampus Gunung Panjang, Jl. Samratulangi, \\ Samarinda, Indonesia \\ *corresponding Ritajojo16@gmail.com
}

\begin{abstract}
One of the efforts to continuously increase lettuce production is by using hydroponic technology. Hydroponics is a way of farming without using soil media but using water or porous materials. Nutrient Film Technique (NFT) including hydroponic farming methods. In this system, some of the roots of the plants are submerged in water that contains fertilizer and some are above the surface of the water with a continuous 24 hours of circulation. The research was conducted from June to November 2020. The research was carried out on the Hydroponic Roof Top of the Red Building. Plantation Cultivation. This research method used a non-factorial randomized block design (RBD), the treatment of $1100 \mathrm{ppm} A B$ Mix nutrition at the age of 1-14 days, $1300 \mathrm{ppm}$ from the age of 21-28 days, $1500 \mathrm{ppm}$ at the age of 29 - 35 days and B2 = Fertilizer Growmore 1100 ppm at the age of $1-14$ and 1300 ppm from the age of 21 - 28 days, 1500 ppm at the age of 29 - 35 days Each treatment consists of 20 sample plants. The results showed a significant difference in the application of $A B$ Mix fertilizer to Growmore fertilizer from week 1 to week IV on plant height increase, number of leaves and wet weight or yield on lettuce plants.
\end{abstract}

Keywords: Hidroponics, Lettuce, AB Mix and Growmore.

\section{PENDAHULUAN}

Tanaman selada merupakan salah satu sayuran yang banyak disukai masyarakat, mempunyai nilai komersil dan prospek yang baik untuk dikembangkan di Indonesia. Tanaman selada ini memiliki kandungan gizi yang cukup baik, setiap $100 \mathrm{~g}$ terdapat protein $1,20 \mathrm{~g}$; lemak 0,20 g; karbohidrat 2,90 g; Ca 22 mg; P 25 mg; Fe 0,50; vitamin A 162 mg; vitamin B 0,04 $\mathrm{mg}$; dan vitamin C $8,00 \mathrm{mg}$ (Yelianti, 2011).

Salah satu upaya untuk meningkatkan produksi selada secara kontinyu adalah dengan menggunakan teknologi hidroponik. Hidroponik adalah cara bercocok tanam tanpa menggunakan media tanah melainkan menggunakan air atau bahan porous (Lingga, 2005). Budidaya tanaman secara hidroponik memiliki beberapa keuntungan yaitu pertumbuhan tanaman dapat dikontrol, tanaman yang diproduksi lebih berkualitas, tanaman jarang terserang hama penyakit, pemberian larutan unsur hara lebih efektif dan efisien karena dapat disesuaikan dengan kebutuhan tanaman tersebut, dapat diusahakan terus menerus tidak tergantung musim, dan dapat diterapkan pada lahan sempit (Istiqomah, 2006).

Salah satu metode dalam hidroponik yaitu hidroponik Nutrient Film Technique (NFT). Metode ini dilakukan dengan meletakkan akar tanaman pada air nutrisi yang dangkal disirkulasikan secara terus menerus selama 24 jam. 
Manulang, R. R., Roby, Mentari, F.S.D, dan Rusmini .(2021) "Pertumbuhan dan Produksi Tanaman Selada (Lactuca sativa L.) Pada Sistem Hidroponik NFT Dengan Berbagai konsentrasi Pupuk AB Mix dan Growmore", Jurnal Agriment, 6(2).

Lapisan air tersebut sangat tipis yaitu sekitar $3 \mathrm{~mm}$ sehingga mirip film. Oleh karena itu teknik ini disebut sistem NFT (Untung, 2000).

Sumber nutrisi yang digunakan dalam budidaya hidroponik adalah dengan menggunakan pupuk dan umumnya menggunakan pupuk anorganik salah satunya adalah larutan nutrisi $A B$ Mix. Kandungan unsur hara dalam $5000 \mathrm{~g}$ larutan nutrisi $A B$ Mix yaitu $\mathrm{Ca}$ (NO3) $21100 \mathrm{~g}, \mathrm{~K}(\mathrm{NO} 3) 2530 \mathrm{~g}$, Fe $86 \mathrm{~g}$, dan MgSO4 4,2 g (Mairusmianti, 2011). Pupuk Growmore ini juga dapat membantu mempercepat pertumbuhan dan perkembangan tanaman, hal ini disebabkan karena selain mengandung unsur hara makro dan mikro, pupuk ini juga mengandung hormon pertumbuhan tanaman. Pupuk ini juga mempercepat keluarnya bunga, mempercepat masa panen sehingga panen lebih cepat dari biasanya.

\section{METODOLOGI}

\section{A. Tempat, Alat dan Bahan Penelitian}

Penelitian ini dilaksanakan di Roof Top Hidroponik Gedung Merah. Budidaya Tanaman Politeknik Pertanian Negeri Samarinda. alat-alat yang digunakan dalam penelitian ini antara lain: drum plastik, mesin pompa air, box kabel roll, over staker saklar 2 lubang, TDS EC, pH meter air, selang, alat dokumentasi, bak semai dam ATK. Sedangkan bahan yang digunakan benih Selada, Nutrisi AB Mix sayur daun, pupuk hantu, net pot, rock woll, air, baja ringan, paranet, talang air, plastik UV, baut.

\section{B. Pelaksanaan Penelitian}

1. Pembuatan Instalasi dari talang yang telah dilubangi dengan jarak $15 \times 15 \times 15$ $\mathrm{cm}$ dan disusun sejajar. Di lubang diberi netpot yang diberi rockwoll dipotong kecil-kecil.

2. Penyemaian benih selada mengunakan trai semai $15 \times 30 \mathrm{~cm}$. Penyemaian dilakukan selama 2 minggu ( bibit berukuran 2 - $3 \mathrm{~cm}$ dan daun 3 helai.

3. Pemberian Nurisi $A B$ Mix dan Growmore sesuai perlakuan pada tandon air. Kemudian menanam bibit selada dengan memasukkan ke dalam netpot yang telah terisi rockwoll

4. Penyulaman tanaman yang layu, mati atau terserang $\mathrm{H} / \mathrm{P}$. Penyulaman dilakukan sampai tanaman berumur 2 minggu setelah tanam dengan bibit yang di semai sama.

5. Panen dilakukan setelah tanaman berumur 35 hst. Dengan cara mengangkat Netpot tanaman dan mencabut tanaman dari netpot tersebut.

\section{Parameter yang Diamati}

1. Tinggi Tanaman

Pengukuran tinggi tanaman dilakukan mulai tanaman berumur 1 minggu setelah tanam hingga minggu ke IV setelah tanam. Tinggi tanaman diukur mulai dari pangkal batang sampai ke ujung titik tumbuh tanaman sampel.

\section{Jumlah Daun}

Jumlah daun dihitung mulai dari daun muda yang telah terbuka sempurna sampai daun yang paling tua. Perhitungandaun tanamandilakukan pada rumur 1 minggu setelah tanaman sampai 4 minggu setelah tanam.

3. Bobot basah pertanaman sampel $(\mathrm{g})$ Pengamatan bobot basah dilakukan dengan cara menimbang tanaman yang telah dibersihkan dan dipotong dari akarnya. Penimbangan dilakukan pada saat panen per sampel tanaman menggunakan timbangan.

\section{Analisis Data}

Pengolahan data menggunakan statistik parametik dengan menggunakan model liner aditif dan dalam Rancangan Acak Kelompok Untuk mengetahui pengaruh perlakuan terhadap peubah 
yang diamati dilakukan analisis ragam (uji F) pada taraf nyata $5 \%$. Jika pada uji $F$ perlakuan menunjukkan pengaruh yang nyata maka dilanjutkan dengan uji beda nilai tengah dengan menggunakan Uji Beda Nilai Tengah (BNT) dan analisa regresi pada taraf nyata $5 \%$ untuk mengetahui hubungan antara perlakuan dengan peubah yang diamati. Jika dengan uji BNT pada taraf $5 \%$ rata-rata perlakuan menunjukkan perbedaan.

\section{HASIL DAN PEMBAHASAN}

\section{A. Hasil Penelitian}

1. Pertambahan tinggi tanaman

Berdasarkan pengukuran tinggi tanaman selada pada penelitian pemberian pupuk $A B$ Mlx dan pupuk Growmore pada minggu 1 hingga minggu ke IV pertambahan tinggu tanaman dari minggu ke I hinggga minggu ke IV dapat dilihat pada Tabel 1 berikut ini :

Tabel 1. Sidik ragam rerata pertambahan tinggi tanaman pada minggu ke I sampai Minggu ke IV Pada perlakuan pemberian AB Mix dan Growmore

\begin{tabular}{|c|c|c|}
\hline \multirow{2}{*}{ Minggu } & \multicolumn{2}{|c|}{ Perlakuan } \\
\hline & AB Mix & Growmore \\
\hline I & $2.95 \mathrm{a}$ & $1,25 \quad b$ \\
\hline II & $5.85 \quad \mathrm{a}$ & $4,65 \quad b$ \\
\hline III & $7,60 \quad \mathrm{a}$ & $7,30 \quad b$ \\
\hline IV & $8,60 \quad a$ & $8,35 \quad b$ \\
\hline
\end{tabular}

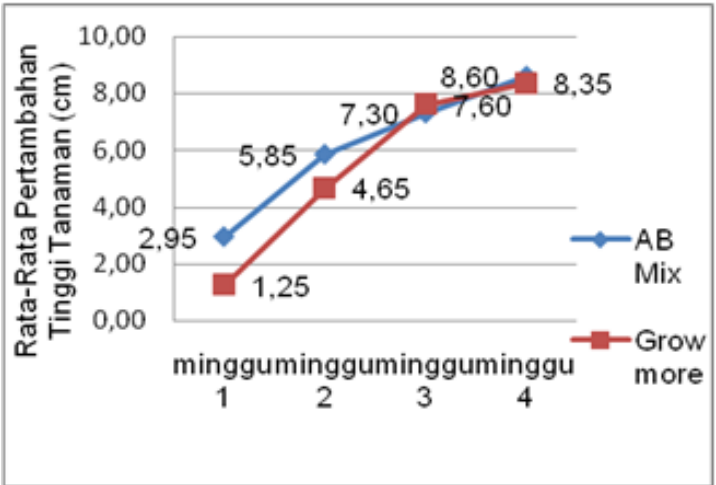

Gambar 1. Grafik Pertambahan Tinggi Tanaman Selada Umur 1 Minggu, 2 Minggu, 3 Minggu dan 4 Minggu Setelah Tanam

2. Pertambahan Jumlah Daun
Berdasarkan hasil sidik ragam terhadap rerata pertambahan jumlah menunjukkan perbedaan nyata pada perlakuan pemberian pupuk $A B$ Mix dan pupuk Growmore pada minggu 1 hingga minggu ke IV, dapat dilihat pada tabel 2 dan pada gambar grafik 2 berikut ini

Tabel 2. Sidik ragam rerata pertambahan tinggi tanaman pada minggu ke I sampai Minggu ke IV Pada perlakuan pemberian AB Mix dan Growmore

\begin{tabular}{ccccc}
\hline Minggu & \multicolumn{4}{c}{ Perlakuan } \\
\cline { 2 - 4 } & \multicolumn{2}{c}{ AB Mix } & \multicolumn{3}{c}{ Growmore } \\
\hline I & 1.25 & $\mathrm{a}$ & 1,20 & $\mathrm{~b}$ \\
II & 1.50 & $\mathrm{a}$ & 1.10 & $\mathrm{~b}$ \\
III & 5,45 & $\mathrm{a}$ & 3,64 & $\mathrm{~b}$ \\
IV & 5.85 & $\mathrm{a}$ & 3,55 & $\mathrm{~b}$ \\
\hline
\end{tabular}



Gambar 2. Grafik Pertambahan Jumlah Daun Selada Umur 1 Minggu, 2 Minggu, 3 Minggu dan 4 Minggu Setelah Tanam

\section{Berat basah panen}

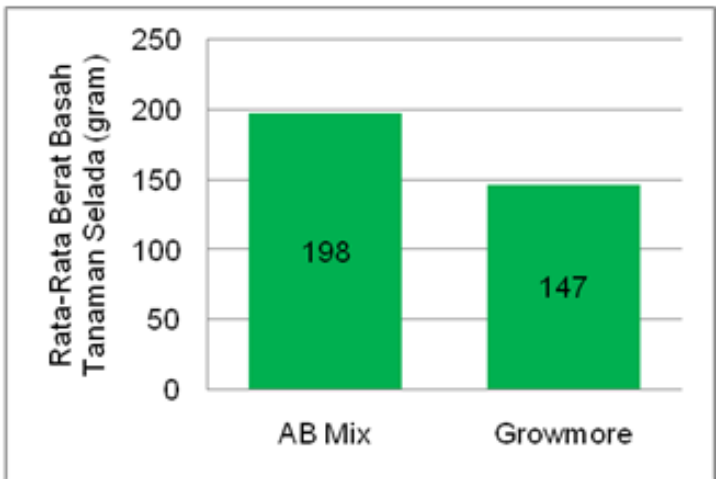

Gambar 3. Grafik Rata-Rata Berat Basah Tanaman Selada (gram) 
Manulang, R. R., Roby, Mentari, F.S.D, dan Rusmini .(2021) "Pertumbuhan dan Produksi Tanaman Selada (Lactuca sativa L.) Pada Sistem Hidroponik NFT Dengan Berbagai konsentrasi Pupuk AB Mix dan Growmore", Jurnal Agriment, 6(2).

Panen pada tanaman selada dilakukan pada minggu ke IV setelah tanam ( 35 hari) baik pada perlakuan pemberian pupuk $A B$ mix maupun Growmore. Hasil penimbangan berat tanaman selada dapat dilihat pada gambar grafik 3.

\section{B. Pembahasan}

1. Pertambahan tinggi tanaman selada

Pada minggu ke 1, pertambahan tinggi tanaman hasil dari pemberian pupuk AB Mix dan pupuk Growmore dosis 1100 ppm secara analisis sidik ragam telah memberikan hasil yang sangat signifikan. $\mathrm{Hal}$ ini berarti bahwa pemberian pupuk $A B$ Mix pada minggu pertama saja sudah lebih unggul dalam meningkatkan tinggi tanaman selada dibandingkan pupuk Growmore menggunakan tehnik hidroponik model NTF ini. Adapun ratarata pertambahan tinggi tanaman menggunakan $A B$ Mix adalah $2,95 \mathrm{~cm}$ sedangkan rata-rata pertambahan tinggi tanaman menggunakan Growmore adalah $1,25 \mathrm{~cm}$.

Pada minggu ke 2, pupuk $A B$ Mix dan Growmore yang telah diberikan di awal minggu pertama dengan dosis 1100 ppm tetap memberikan hasil yang sangat signifikan dan merupakan hasil penyerapan yang sempurna dari $A B$ Mix ke tubuh tanaman sehingga lebih unggul dibandingkan pupuk Growmore dalam meningkatkan pertambahan tinggi tanaman selada.

Pada minggu ke 3 pengamatan, setelah diberikan pupuk $A B$ Mix dan Growmore dengan dosis 1300 ppm terlihat bahwa pada pupuk Growmore memberikan kenaikan yang cukup baik untuk pertambahan tinggi (rata-rata 7,6 $\mathrm{cm}$ ) dibandingkan pupuk $A B$ mix (rata-rata $7,3 \mathrm{~cm}$ ) namun berdasarkan pembacaan tabel analisis sidik ragam (ANOVA) kedua perlakuan tersebut memberikan hasil yang tidak signifikan. Artinya pemilihan AB Mix maupun Growmore untuk umur 21 - 28 hari sama-sama dianjurkan bagi peningkatan tinggi tanaman selada.

Pada minggu ke 4, setelah diberikan pupuk $A B$ Mix dan Growmore dengan dosis 1500 ppm terlihat bahwa pada pupuk $A B$ Mix lebih baik untuk pertambahan tinggi (rata-rata $8,6 \mathrm{~cm}$ ) dibandingkan pupuk Growmore (rata-rata 8,35 cm) namun berdasarkan pembacaan tabel analisis sidik ragam (ANOVA) kedua perlakuan tersebut memberikan hasil yang tidak signifikan. Artinya pemilihan AB Mix maupun Growmore dosis 1500 ppm untuk umur 29 - 35 hari dapat dipakai bagi peningkatan tinggi tanaman selada.

Perbandingan antara nutrisi growmore dengan nutrisi $A B$ Mix ini dapat dijelaskan bahwa pada hara yang terkandung dalam nutrisi $A B$ mix lebih tinggi dibandingkan dengan nutrisi growmore. Kemudian, pada pertumbuhan tanaman selada yang diberikan nutrisi $A B$ Mix lebih cepat tumbuh dan lebih besar dibandingkan dengan tanaman selada yang diberikan dengan nutrisi Growmore. Hal ini terjadi karena, penyerapan unsur hara yang terkandung dalam nutrisi $A B$ Mix cenderung lebih cepat dibandingkan dengan nutrisi Growmore. Pada nutrisi AB Mix pertumbuhan tanaman selada hidroponik memperlihatkan hasil yang lebih baik, hal ini dikarenakan nutrisi ABmix mudah terlarut sehingga mudah diserap oleh tanaman.

Menurut Lingga (2002) menyatakan bahwa kepekatan pupuk organik cair yang dilarutkan dalam sejumlah air harus tepat dan sesuai dengan kebutuhan tanaman selada hidroponik. Pada kepekataan yang lebih rendah mengakibatkan efektivitas pupuk menjadi berkurang, sehingga menyebabkan daun tanaman menjadi kuning, layu dan bahkan mati. Sedangkan jika berlebihan maka akibatnya tanaman akan layu atau bahkan mati.Wijayani dan Widodo (2005) menambahkan larutan 
yang pekat tidak dapat diserap oleh akar tanaman secara maksimum, hal ini disebabkan oleh tekanan osmose sel menjadi lebih kecil dibandingkan dengan tekanan osmose diluar sel sehingga kemungkinan akan terjadi aliran balik cairan sel-sel tanaman (plasmolysis).

\section{Pertambahan jumlah daun selada}

Pada minggu ke 1, kedua perlakuan yang diberikan baik pupuk $A B$ Mix maupun pupuk Growmore dengan dosis 1100 ppm (umur 1 - 14 hari) belum memberikan hasil yang signifikan. Kedua pupuk tersebut masih mempengaruhi dalam jumlah yang kurang lebih sama untuk pertambahan jumlah daun tanaman selada yang dijadikan sampel pengamatan.

Pada minggu ke 2 pengamatan, berdasarkan analisis sidik ragam menggunakan Rancangan Acak Kelompok Non Faktorial mulai terlihat bahwa perlakuan memberikan hasil yang signifikan di mana pemberian pupuk $A B$ Mix lebih unggul dibandingkan dengan pemberian pupuk Growmore. Hal ini dapat diartikan bahwa penyerapan pupuk $A B$ Mix dengan dosis 1100 ppm yang diberikan mulai terserap maksimal pada tubuh tanaman dan memberikan pertambahan jumlah daun (rata-rata pertambahan sebesar 1,5 helai) yang lebih berarti dibandingkan pupuk Growmore (rata-rata pertambahan sebesar 1,1 helai)

Pada minggu ke 3 pengamatan terlihat bahwa pemberian pupuk $A B$ Mix dan Growmore dengan dosis 1300 ppm ( umur 21 - 28 hari) memberikan hasil yang sangat signifikan dan terlihat sangat jelas bahwa pupuk AB Mix (rata-rata pertambahan jumlah daun 5,45 helai) lebih unggul dibandingkan Growmore (rata-rata pertambahan jumlah daun 3,4 helai) sehingga disarankan penggunaan pupuk $A B$ Mix dengan dosis 1300 ppm untuk tanaman selada dengan system hidroponik NFT pada usia 21 - 28 hari setelah penanaman.
Pada minggu ke 4, hasil dari pemberian pupuk $A B$ Mix dan Growmore yang telah ditingkatkan menjadi 1500 ppm juga memberikan hasil yang sangat signifikan dan tetap mengunggulkan pupuk $A B$ Mix untuk disarankan lebih baik dalam penggunaan tanaman selada umur 29 - 35 hari setelah penanaman.

Jadi dalam hal pertambahan jumlah daun pemberian pupuk $A B$ Mix ternyata lebih baik dibandingkan pemberian pupuk Growmore.

Adanya penambahan jumlah daun di setiap minggunya diduga pada tanaman selada yang menyerap unsur $\mathrm{N}$ mulai membetuk daun dengan cadangan makanannya, sehingga lebih banyak digunakan dalam pembentukan daun baru. Kemudian hal ini juga diperkuat dengan pernyataan oleh Fitter dan Hay (1992) bahwa klorofil dalam tanaman sebagian besar berada dibagian daun tanaman. Karena itu, daun memegang peranan penting dalam penangkapan cahaya matahari. Penangkapan cahaya oleh daun sangat dipengaruhi oleh morfologi daun seperti lebar, selain di pengaruhi oleh klorofil yang ada di daun. Daun merupakan organ penting bagi tanaman karena berperan dalam proses fotosintesis. Daun memiliki klorofil dimana jumlah klorofil yang tinggi akan menyebabkan proses dari fotosintesis berjalan dengan baik. Semakin lebar luas daun, maka penerimaan cahaya matahari pada tanaman akan lebih banyak. Cahaya matahari merupakan sumber energi yang digunakan untuk melakukan pembentukan fotosintat. Dengan luas daun yang tinggi, maka cahaya akan dapat lebih mudah diterima oleh daun dengan baik.

Hal ini terjadi diduga karena, tinggi tajuk selada dipengaruhi oleh panjang akar dimana akar merupakan organ penting dalam penyerapan ion-ion, kecepatan fotosintesis dan aktivitas enzim. Semakin panjang akar, maka semakin besar cakupan nutrisi yang diserap, sehingga nutrisi yang dibutuhkan 
Manulang, R. R., Roby, Mentari, F.S.D, dan Rusmini .(2021) "Pertumbuhan dan Produksi Tanaman Selada (Lactuca sativa L.) Pada Sistem Hidroponik NFT Dengan Berbagai konsentrasi Pupuk AB Mix dan Growmore", Jurnal Agriment, 6(2).

tanaman akan membentuk energi yang tersimpan didalam batang yang menyebabkan pertumbuhan pada tinggi tajuk. Menurut Chiraz (2013) menunjukkan bahwa terdapat hubungan yang erat antara tinggi tegakkan, diameter batang, cakupan akar dan diameter kanopi. Ukuran tegakan juga menentukan biomassa tanaman baik yang berada diatas permukaan tanah (batang, daun) maupun yang berada dibawah permukaan tanah (akar) (Komiyama et al. 2008). Tinggi tajuk adalah pencerminan panjang batang yang beruas dan berbuku sehingga juga mencerminkan jumlah daun (Awalludin, 2014).

\section{Hasil panen}

Untuk Hasil panen, dengan nilai yang sangat signifikan maka pemberian $A B$ Mix secara keseluruhan lebih unggul dibandingkan pemberian Growmore. Artinya dapat disarankan pemupukan dengan $A B$ Mix sesuai dosis dan umur yang sudah dilakukan dalam penelitian.

Hal ini terjadi diduga karena, pada masa pertumbuhan tanaman yang menggunakan nutrisi $A B$ Mix inilah yang lebih cepat tumbuh, dan larutan nutrisi $A B$ Mix juga lebih cepat larut dalam air, sehingga perakaran dari tanaman mampu lebih cepat untuk menyerap nutrisi yang tersedia dalam air. Oleh karena itu, rerata berat segar tajuk $A B$ Mix relatif tinggi dibandingkan dengan rerata berat segar tajuk yang menggunakan nutrisi formulasi. Hal ini diperkuat oleh Masud (2009) bahwa ketersediaan unsur hara makro dan mikro yang cukup dan sesuai menyebabkan pertumbuhan tanaman akan terpacu secara optimal, sehingga diperoleh hasil produksi berupa berat segar dan berat kering tajuk pada tanaman selada dengan kombinasi perlakuan nutrisi AB Mix buatan sendiri dengan media tanam pasir.

\section{KESIMPULAN}

1. Berdasarkan hasil penelitian pertambahan tinggi tanaman $(\mathrm{cm})$ yang terbaik adalah pemberian pupuk $A B$ Mix baik pada minggu ke I setelah tanam hingga minggu ke IV setelah tanaman dengan rerata 2,95, 5,85, 7,60 dan 8,60 dibanding dengan pupuk growmore dengan rerata pertambahan tinggi tanaman $1,25,4,65,7,30$ dan 8,65 .

2. Berdasarkan hasil penelitian pertambhaan jumlah daun (helai) yang terbaik adalah pemberian pupuk $A B$ Mix baik pada minggu ke 1 setelah tanam hingga minggu ke IV setelah tanaman dengan rerata $1.25,1.5,5.45$ dan 5.85 dibanding dengan pupuk growmore dengan rerata pertambahan jumlah daun 1.20, 1.10, 3.64 dan 3.55.

3. Berdasarkan hasil penelitian berat basah tanaman lada setelah panen hasil terbaik adalah pemberian pupuk AB Mix dengan rerata $198 \mathrm{~g}$ sedangkan pemberian pupuk Growmore seberat $147 \mathrm{~g}$.

\section{UCAPAN TERIMA KASIH}

1. Mengucapkan terima kasih kepada Kementerian Pendidikan dan Kebudayaannya atas bantuannya dalam hal penyediaan Dana untuk penelitian.

2. Mengucapkan terima kasih kepada Direktur Politeknik Pertania Samarinda yang telah menyalurkan Dana untuk penelitian.

3. Kepada P2M atas kerjasamanya dalam mengelolaan penelitian ini.

4. Dan semua dosen BTP atas kerjasamanya hingga penelitian ini dapat berakhir.

\section{DAFTAR PUSTAKA}

Anonim.(2009). http://www.refadd.com/Hantutanaman Multiguna.

Awaluddin, M. dkk. (2014). Hidroponik praktis. Jakarta : Trubus Swadaya.

Cahyono. (2005). Budidaya Tanaman Sayuran. Jakarta:Penebar Swadaya. 
Chaidirin, Y. (2001). Pelatihan Aplikasi Teknologi Hidroponik Untuk Pengembangan Agribisnis Perkotaan. Lembaga Pertanian Institut Pertanian Bogor. Bogor.

Chiraz, M.C. (2013). Growth of Young Olive Trees: Water Requirement in Relation to Canopy and Root Development. American Journal of Plant Sciences .

Istiqomah, S. (2014). Menanam Hidroponik. Jakarta: Azka press.

Lingga , P dan Marsono. (2002) . Petunjuk Penggunaan Pupuk. Jakarta : Penebar Swadaya.

Lingga, P. (2005). Hidroponik, Bercocok Tanam Tanpa Tanah. Jakarta : Penebar Swadaya.

Mas'ud, H. (2009). Sistem Hidroponik dengan Nutrisi dan Media Tanam Berbeda. Terhadap Pertumbuhan dan Hasil Sekada. Jurnal. Media Litbang. Sulteng.

Noverita. (2005). Pengaruh konsentrasi pupuk pelengkap cair Nipka - Plus dan jarak tanam terhadap pertumbuhan dan produksi tanaman baby kaylan (Brassica oleraceae L.) secara vertikultur. Jurnal Penelitian Bidang Ilmu Pertanian.

Otazu, V.(2010). Manual On quality seed potato production using aeroponics. International Potato Center (CIP). Lima. Peru.

Rasapto, P. (2006). Budidaya Sayuran Dengan Vertikultur. Temu Teknis Nasional Tenaga Fungsional Pertanian. Balai Pengkajian Teknologi Pertanian Jawa Tengah.

Sanusi, B. (2010). Sukses Bertanam Sayuran di Lahan Sempit. Jakarta Selatan : Agromedia Pustaka.

Zulfitri. 2005. Analisis Varietas Dan Polybag Terhadap Pertumbuhan Serta Hasil Cabai (Capsicum Annum L.) Sistem Hidroponik. Bulletin Penelitian.

Untung. (2000). Hidroponik Sayuran Sistem NFT, Jakarta :Penebar Swadaya.

Wijayani A, Widodo W. (2005). Usaha Meningkatkan Kualitas Beberapa Varietas. Tomat dengan Sistem
Budidaya Hidroponik. Ilmu Pertanian, Vol (12). N0.1: 77-83.

Yelianti, U. (2011). Respon tanaman selada (Lactuca sativa L.) terhadap pemberian pupuk hayati dengan berbagai agen hayati. Jurnal Biospecies, 4(2): 35-39 